\title{
Regeneration patterns of Quercus suber according to montado management systems
}

\author{
M. Paula Simões $\cdot$ Anabela F. Belo • \\ Mariana Fernandes $\cdot$ Manuel Madeira
}

Received: 16 June 2014/ Accepted: 21 May 2015/Published online: 29 May 2015

(C) Springer Science+Business Media Dordrecht 2015

\begin{abstract}
Traditional management of montado (dehesa) is an example of integration of sustainable landuse and biodiversity conservation. The whole system sustainability is currently threatened by the intensification of soil tilling to control shrub invasion and promote pastureland, the absence of tree natural regeneration being one of the most outstanding threats. A study to assess effects of management on tree regeneration at early stages was developed in a cork oak montado grazed by cattle, in southern Portugal. We specifically compared the effects of harrowing every 3-4 years with those of shrub clearing with a shredder every 5-7 years. We hypothesized that extending shrub maintenance may facilitate cork oak regeneration at early stages in grazed montado. Fenced
\end{abstract}

M. P. Simões · A. F. Belo $(\bowtie)$

ICAAM - Instituto de Ciências Agrárias e Ambientais Mediterrânicas, Universidade de Évora, Núcleo da Mitra, 7002-554 Évora, Portugal

e-mail: afb@uevora.pt

M. P. Simões

e-mail: mps@uevora.pt

M. P. Simões · A. F. Belo · M. Fernandes Departamento de Biologia, Escola de Ciências e Tecnologia, Universidade de Évora, Ap. 94, 7002-554 Évora, Portugal

M. Madeira

Centro de Estudos Florestais, Instituto Superior de Agronomia, Universidade de Lisboa, Tapada da Ajuda, 1349-017 Lisbon, Portugal cork oak paddocks under the same management system for at least the last 40 years were surveyed for cork oak seedling, juvenile and sapling density; shrub cover percentage was also estimated. Recruitment bottleneck was observed after the seedling stage under harrowing, while in shredded areas all stages were well represented and often associated with shrub patches. Overall, the highest cork oak recruitment occurred at intermediate shrub cover (40-60\%). By maintaining shrub patches and their protective effect against direct radiation and grazing impact, while preventing shrub encroachment, shredding every 7 years seems to create an important temporal window for effective oak regeneration. This management practice might thus be suitable to favour successful tree regeneration in grazed cork oak montado, assuring the persistence of this system.

Keywords Grazing - Harrowing - Quercus suber . Regeneration $\cdot$ Shredding

\section{Introduction}

Mediterranean cork oak (Quercus suber L.) savanna (called montado in Portugal and dehesa in Spain) is found only in southwestern Europe and northwestern Africa. Cork oak montado presents a tree density ranging 20-100 adult trees ha ${ }^{-1}$ (DGRF 2007) and is distinguished by a systematic combination of agricultural, pastoral, and forestry uses. The traditional land- 